\title{
O romskim zespole pieśni i tańca Kałe jakha w zakopiańskim archiwum Wojciecha Jarzębowskiego
}

Dokumentację dotyczącą romskiego zespołu zgromadzoną w ciągu blisko dwudziestu lat przez Wojciecha Jarzębowskiego otrzymałam w 2018 roku od wdowy po nim — pani Ewy ${ }^{1}$. Z dużym zainteresowaniem przeglądnęłam dar i uznałam, że jest to niezwykle cenny zasób wiedzy o historii Podhala i Zakopanego w kontekście dziedzictwa Romów. Romowie z grupy nazwanej Romami Karpackimi lub - jak sami siebie czasami określają - Amare Roma (Nasi Romowie) są mieszkańcami Podhala i współtworzą lokalną kulturę od kilku stuleci. Na początku XX wieku Bronisław Piłsudski, etnograf i językoznawca, w jednym z punktów programu dla powstającego działu ludoznawczego Muzeum Tatrzańskiego uznał za słuszne i ważne, aby objąć tę społeczność etnograficznym zainteresowaniem. To istotne stwierdzenie zapisane przez uczonego stało się motywacją do napisania tego artykułu.

Wojciech Jarzębowski (1926-2004) był zakopiańskim dziennikarzem i fotografikiem. Przez wiele lat pracował dla gazety „Dziennik Polski”, był założycielem i kierownikiem Zakopiańskiego Artystycznego Zespołu Cygańskiego muzyki, pieśni i tańca „Kałe jakha”” („Czarne oczy”). Przewodniczył Radzie tego zespołu, który działał pod patronatem „Dziennika Polskiego”. W sierpniu 1982 zespół został zarejestrowany przy Wydziale Kultury Miasta Zakopanego i Gminy Tatrzańskiej, a w kolejnym roku stał się członkiem Tatrzańskiego Towarzystwa Kulturalnego (dalej: TTK). W archiwum zachowały się dowody wpłat składki za członkostwo w TTK za lata 1983-1993.

Dokumentacja archiwalna obejmuje lata od 1982 do początku 2000. Tworzy ją zeszyt w kratkę formatu A4, książka Jerzego Ficowskiego Cyganie na polskich drogach (wyd. 1986), liczne wycinki prasowe o bieżących wydarzeniach dotyczą-

1 W tym miejscu jeszcze raz bardzo dziękuje pani Ewie Jarzębowskiej za ten dar.

2 Pisownia nazw zespołu, tytułów pieśni oraz ich tłumaczenia są zgodne $\mathrm{z}$ dokumentami $\mathrm{w}$ archiwum W. Jarzębowskiego. 
cych Romów i dwie koperty formatu A4 z różnymi dokumentami — maszynopisami. Gruby zeszyt w kratkę, który można określić jako księgę pamiątkową, zawiera najwięcej ręcznie zapisanych informacji na temat przeprowadzonych prób i występów zespołu, a archiwalia w dwóch kopertach są ich uzupełnieniem.

Zespół Kałe jakha tworzyła przede wszystkim młodzież ze wsi Skalnego Podhala, Zakopanego, Nowego Targu, Rabki i Czarnego Dunajca. W notatkach Jarzębowskiego jest także umieszczona informacja o romskich muzykach z Nowej Huty, którzy okazjonalnie włączali się w działania artystyczne. Głównym celem założenia zespołu miało być ,zintegrowanie społeczności cygańskiej zamieszkującej Zakopane, Skalne Podhale i Podhale", jak napisał Jarzębowski. W 1989 roku zespół zmienił nazwę na Zespół Cyganów Górskich muzyki, pieśni i tańca Tatrzańskiego Towarzystwa Kulturalnego „Bergary”3 (w dialekcie Polskiej Romy berg znaczy „góra”). Działał on do początku pierwszej dekady XXI wieku.

Różnorodny zasób archiwum Jarzębowskiego jest dowodem bardzo dużego zaangażowana jego właściciela w promowanie romskiej kultury oraz wspierania lokalnej społeczności. Kierowała nim wyraźna do niej życzliwość i sympatia. Jarzębowski organizował próby zespołu, przygotowywał jego występy, starał się dla niego o wsparcie finansowe i publikował rozliczne tematyczne artykuły na łamach „Dziennika Polskiego”. Pozostawione przez niego rękopisy i maszynopisy, wycinki z prasy, fotografie czarno-białe i kolorowe, korespondencja, rachunki, plakaty z występów zespołu, brudnopisy, dwa ręcznie napisane listy od Romów do Jarzębowskiego, drobne notatki z bieżących wydarzeń i przemyślenia stanowią interesujące i cenne źródło do poznania działalności tego zespołu i związanej z nim historii Romów z Podhala w ostatnich dwóch dekadach XX wieku.

Jarzębowski systematycznie poszerzał swoją wiedzę na temat romskiej kultury, na marginesach książki Ficowskiego umieszczał drobne zapiski, a na pojedynczych kartach notował to, co w niej przeczytał, gromadził liczne artykuły wycięte z prasy, które dotyczyły różnych tematów odnoszących się do społeczności romskiej. Skrupulatnie je gromadził, umieszczał datę opublikowania informacji i podkreślał zdania uznane przez niego za szczególnie ważne.

Starał się pomagać w życiu codziennym członkom zespołu, więc pisał listy do urzędów, prosząc w imieniu Romów o wsparcie finansowe albo o zatrudnienie ich przy pracach budowlanych. Wzruszający jest list Jarzębowskiego napisany 13 grudnia 1983 i skierowany do dowództwa jednostki wojskowej w Bochni koło Krakowa, w której Julian Mirga z Czarnego Dunajca odbywał służbę. W liście Jarzębowski prosi o skierowanie mężczyzny do garnizonu zakopiańskiego, batalionu budowlanego w Kościelisku. List został napisany na prośbę Juliana, o którym

3 W planach było wprowadzenie nazwy Amatorski Zespół Cyganów Górskich muzyki, pieśni, tańca „Górska Roma” (Bergitka Roma). 
Jarzębowski wiedział, że jest szanowany przez członków swojej społeczności, a sam cenił jego talent jako tancerza. W ostatnich akapitach listu napisał:

Julian Mirga dał się poznać jako aktywista w pracy społecznej, ponieważ jest utalentowanym tancerzem i występuje w Zespole, cieszy się więc autorytetem. Bez tego typu ludzi „Dziennik Polski” nie zdziałałby wiele na polu wychowawczym w tej społeczności [...]. Możliwość przeniesienia Juliana Mirgi jako żołnierza w pobliże środowiska cygańskiego, z którego wyszedł, gdzie mógłby nadal oddziaływać, bowiem jest bardzo pozytywną jednostką — fakt ten byłby bardzo korzystny w naszej pracy w tym środowisku i bylibyśmy wdzięczni za załatwienie tej sprawy.

W innym liście natomiast, skierowanym do dyrekcji Zakładów Przemysłu Jedwabniczego „Miranda” w Turku, z 18 października 1983 prosi zaś o przesłanie do zakopiańskiego sklepu tkaniny lureks, która jest najbardziej odpowiednia do uszycia strojów cygańskich. Przy tej okazji w kilku zdaniach przypomina o celu założenia zespołu:

redakcja „Dziennika Polskiego” poprzez swój oddział w Zakopanem sprawuje patronat i opiekę nad społecznością cygańską na Podhalu. Załatwiamy pracę, pomoc materialną, zdrowotną i prowadzimy działalność oświatową.

Jarzębowski skrupulatnie prowadził kronikę od pierwszych dni działalności zespołu. Dowiadujemy się z niej, że 27 sierpnia 1982 odbyła się pierwsza próba i została sporządzona lista obecności. W kilku zdaniach zanotował wrażenia ze spotkania, które zakończył stwierdzeniem: „pierwsze lody chyba zostały przełamane". Kolejna próba miała miejsce tydzień później. Wiadomo, że odbywały się one w zakopiańskim ośrodku kultury w każdy piątek o godzinie piątej po południu. Poniżej daty każdego spotkania Jarzębowski zapisywał własne spostrzeżenia i wrażenia z pierwszych miesięcy istnienia zespołu:

— 17 września zanotował: „przyszedł na próbę i grał Michał Mirga z Zadziału koło Szaflar - znakomity skrzypek. Przyszła też starsza Cyganka Anna Jaśkowiak, która instruowała dziewczęta w tańcu". W tym dniu próbie przyglądali się dziennikarze;

— 24 września: „Pani Gładczan z [Zespołu Bartusie] wzięła miarę na szycie spódnic dla kilku dziewcząt. Zespół chce zakupić używane basy na własność”;

-27 września wkleił fotografie z próby i podpisał, kto jest na nich przedstawiony;

— 28 września zanotował: „kupiliśmy basy za 2500 zł, planujemy kupić skrzypce, ale jak na razie brak pieniędzy, przyjęliśmy dwójkę nowych członków - utalentowaną tancerkę i tancerza";

- 7 października umieścił listę obecności osób zgromadzonych na próbie: sekcja dzieci (Iwona Mirga, Michał Mirga), sekcja dziewcząt (Małgorzata Jaśkowiak, Bogusława Jaśkowiak, Magda Mirga, Ewa Mirga, Paloma Jaśkowiak, Barbara Jaśkowiak, Lidia Mirga, Beata Gabor, Barbara Gabor, Fatima Oraczko, Renata Mirga, Bożena Mirga), sekcja chłopców (Paweł Mirga, Władysław Bur- 
jański, Piotr Jaśkowiak, Ryszard Gil, Kazimierz Szczerba, Zenon Gabor, Stanisław Olszowski, Florian Mirga, Antoni Mirga), kierownik artystyczny i reżyser - Wiesław Jaśkowiak, kierownik zespołu - Wojciech Jarzębowski, patronat Redakcji „Dziennika Polskiego”.

W dniu 6 września 1982 ukazała się pierwsza notatka prasowa na temat zespołu, którą przygotował Jarzębowski i opublikował w „Dzienniku Polskim”, a już dziesięć dni później zwrócił się on z prośbą do Zarządu Tatrzańskiego Klubu Kolekcjonerów o dotację na jego działalność. W tym samym miesiącu został opracowany program występu wraz ze spisem uczestników (wymienione są imiona i nazwiska) należących do grupy tanecznej. W kronice zanotował również romskie nazwy poszczególnych układów tanecznych, jak na przykład Romano wurdo - tabor cygański, taciakri cierheń - taniec nocnej gwiazdy (polarnej), tewitynoł okham - przywitanie słońca, teciarino cianoro - czarowanie księżyca. O zwróceniu uwagi na język romski Jarzębowski pamiętał także, przygotowując dla siebie przemówienie przed występem. Na jednej z kartek zapisał: „,na początek pierwsze zdanie powiedzieć po cygańsku".

Występ odbył się 13 października w Zakopanem. Jarzębowski zanotował: „nadkomplet publiczności, ponad 20 dziennikarzy prasy, radia, telewizji oraz dwóch dziennikarzy z Jugosławii”. W innym zaś miejscu kroniki widnieje notatka: „jest propozycja, aby festiwal zespołów cygańskich poprzedził Międzynarodowy Festiwal Folkloru Ziem Górskich [w Zakopanem]". Kilka dni przed występem, 4 października, Jarzębowski opublikował w „Dzienniku Polskim” informację, że „zespołowi Kałe jakha pomagają członkowie Zespołu Bartusia Obrochty z jego kierownikiem panem Tadeuszem Sztromajerem, który zamierza zorganizować wspólny występ artystyczny młodzieży góralskiej i cygańskiej”. Drugi występ romskiego zespołu odbył się 11 grudnia, a trzeci szesnaście dni później. Jarzębowski napisał wówczas: „komplet publiczności, 90-osobowa wycieczka z RFN. Dużo było braw, czyli że występ się podobał. Mamy własne uwagi i spostrzeżenia, które wykorzystamy do dalszej pracy". Zespół prezentował się także podczas zabawy sylwestrowej w Zakopanem.

Do 1984 roku Jarzębowski zapisywał informacje o kolejnych występach artystycznych. W sumie było ich szesnaście.

Po piątym występie, 26 marca 1983, Jarzębowski zanotował w kronice: „występ bardzo udany. Członkowie Zespołu obdarowani zostali paczkami żywnościowymi oraz każdy otrzymał bon odzieżowo-obuwniczy do zrealizowania w późniejszym terminie". Przy okazji dziewiątego występu kilka dni wcześniej ukazały się notatki prasowe autorstwa Jarzębowskiego i Stanisława Kałamackiego pod tytułem Lato z Radiem w Zakopanem, w których zapowiadano bezpośrednią transmisję z Krupówek do Polskiego Radia i Telewizji. Dziesiąty występ odbył się w Limanowej: „występ oglądało kilka tysięcy ludzi [...] przyjęty został bardzo dobrze”. Kolejne miały miejsce podczas sześćdziesięciolecia „Orbisu” w Zakopanem, Dnia Kobiet i w ramach realizowanego w Zakopanem filmu Tumor Witka- 
cego w reżyserii Grzegorza Dubowskiego. Dwa ostatnie występy, o których wiemy z archiwum, odbyły się podczas akademii 22 lipca 1984 w Zespole Domów Wczasowych „Dafne” i kilka dni później podczas „Białodunajeckiego spotkania twórczego". Jarzębowski umieścił notatkę dotyczącą akademii: „występ bardzo się podobał. Wczasowicze z grup zagranicznych Bułgarii i Węgier obdarowali członków Zespołu upominkami”. W programach występów znajdują się tytuły figur tanecznych w językach polskim i romani, a także imiona i nazwiska ich wykonawców.

Dzięki skrupulatności Jarzębowskiego znany jest dokładnie skład zespołu w dniu 23 marca 1983. Ulegał on zmianom, bo pojedyncze osoby odchodziły, a w ich miejsce przychodziły nowe. Do sekcji dziecięcej należeli: Iwonka Mirga (Szaflary), Beata Jaśkowiak (Zakopane), Staś Dunka (Zakopane), Michał Mirga (Szaflary); w sekcji baletowej dziewcząt były: Bogusława Jaśkowiak (Zakopane), Paloma Jaśkowiak (Szaflary), Barbara Jaśkowiak (Czarna Góra), Magda Mirga (Szaflary), Barbara Mirga (Szaflary), Bożena Mirga (Zakopane); w sekcji baletowej chłopców: Julian Mirga (Czarny Dunajec), Władysław Burjański (Czarny Dunajec), Kazimierz Szczerba (Czarny Dunajec), Krzysztof Jaśkowiak (Szaflary), Paweł Mirga (Nowy Targ), Piotr Jaśkowiak (Zakopane), Florian Mirga (Szaflary); w sekcji piosenkarzy: Małgorzata Jaśkowiak (Zakopane), Beata Gabor (Nowy Targ), Lidia Mirga (Nowy Targ), Zenon Gabor (Nowy Targ); a kapelę tworzyli: Michał Mirga (Szaflary), Jakub Gil (Szaflary), Stanisław Jaśkowiak (Szaflary) i Wiesław Jaśkowiak (Zakopane), który był też kierownikiem artystycznym. Kilka miesięcy później do zespołu dołączyli: Beata Mirga (Nowy Targ), Paweł Szczerba (Rabka), Stanisław Styrkacz (Czarny Dunajec), Józef Styrkacz (Czarny Dunajec) i Bernard Burjański (Czarny Dunajec). Gdy w 1989 roku zespół zmienił nazwę na Zespół Cyganów Górskich muzyki, pieśni i tańca Tatrzańskiego Towarzystwa Kulturalnego „Bergary”, kierownikiem artystycznym i głównym instruktorem został Marek Ricardo Czureja, a jego zastępcą Mirosław Pawłowski.

W notatkach Jarzębowskiego zawartych w kronice są również zebrane informacje o kwestiach finansowych - wpływach i realizowanych wydatkach na zakupy elementów stroju dla tancerzy i instrumentów dla muzyków, a także kosztów związanych z wydatkami na podróże uczestników prób, które odbywały się w Zakopanem. W tym celu Jarzębowski zadbał o otworzenie konta bankowego dla zespołu. Zarobione podczas występów pieniądze i środki zebrane z dotacji od różnych instytucji, na przykład Urzędu Miasta Zakopanego, przekazywane były na wyposażenie zespołu w stroje, na zakupy instrumentów lub pomoc materialną dla rodzin. W notatkach Jarzębowskiego można przeczytać na temat wydatków związanych z zakupami między innymi: dziesięciu spódnic, sukienki dla Beaty Jaśkowiak, dziewiętnastu koszul, siedmiu par damskich butów, dziesięciu par męskich butów, pięciu paczek cekinów, sześciu metrów materiału na spódnice dla dzieci, aksamitek i brylancików na opaski ozdobne na głowę, sześciu par kolczyków ze srebrnym uszkiem „cygańskie pawie oko”, sześciu metrów opasek, odpo- 
wiedniego materiału i krajki, pięciu kamizelek dla kapeli, złotej taśmy do kamizelek i tamburyna, a także dwóch kolumn głośnikowych i jednego mikrofonu do śpiewu, które są w komplecie do wzmacniacza elektrycznego do muzyki i śpiewu podarowanego przez dyrekcję PP Hotele „Orbis”, „Kasprowy-Giewont”. Ponadto wydatki obejmowały: szycie sukienek dla Iwonki Mirgi i Stasi Dunki, ślubnej sukni dla zespołu w stylu cygańskim i pięciu różowych bluzek oraz wykonanie trzech opasek na głowę i naprawę akordeonu.

Interesujące są notatki prasowe, które Jarzębowski systematycznie przygotowywał do „Dziennika Polskiego”. Dowiadujemy się z nich o:

— pierwszym pod Giewontem ślubie po cygańsku, który odbył się 14 maja 1983 ;

— ognisku: „22 września 1984 Zespół Cygański w ilości 32 osoby wyjechał na wycieczkę do Zamku w Niedzicy”, następnie odbyło się ognisko z ,pieczoną na patyku kiełbasą";

— nowym programie zespołu z ,gwiazdami taborów cygańskich”, którymi byli Ricardo Czureja — „znany cygański tancerz i piosenkarz”, Beata Mirga-Zielińska — „piosenkarka, przedstawicielka najstarszego rodu Cyganów górskich — Mirgów";

— koncertach zespołu podczas ślubów cywilnych w Zakopanem: „na nową drogę życia przy dźwiękach cygańskich czardaszy" i dalej:

kapela gra rzeczywiście bardzo pięknie i dobrze się prezentuje dlatego też kierownik Urzędu Stanu Cywilnego - Franciszek Szlachta wyraził zgodę, aby przygrywała ona wszystkim wkraczającym na nową drogę życia. Oprócz miłej muzyki są jeszcze życzenia szczęścia dla młodej pary, a wiadomo, że dobre życzenia od Cyganów mają „czarodziejską moc”. Pomysł chwycił i został przyjęty [od sierpnia 1989 roku].

W dokumentacji zebranej przez Jarzębowskiego znajdują się także liczne czarno-białe i kolorowe fotografie. Ukazują one różne figury taneczne, członków zespołu podczas występu w Limanowej, ogólnopolskich targów staroci w Zakopanem i Wielkich Targów Kolekcjonerskich. Na fotografiach uchwyceni są Romowie, którzy z zaangażowaniem pomagają przy wydarzeniu i prezentują przedmioty przeznaczone do licytacji. Na innych zdjęciach widoczne są liczne osoby z zainteresowaniem oglądające występy zespołu, a wśród nich redaktor telewizyjny Ryszard Goczał, który realizuje dokumentację filmową spotkania.

Pamięć o romskim zespole wśród mieszkańców Zakopanego jest żywa. Interesujące mogą być współczesne rozmowy na temat wydarzeń minionych lat i wspomnienia tych, którzy w nich uczestniczyli. Ukażą one rzeczywistość, której już nie ma, ale która pozostawiła ślad w ludzkiej pamięci, stwarzający szansę dalszych pogłębionych badań. W ostatnich dziesięcioleciach Romowie z Podhala licznie wyemigrowali na Zachód, ale w zeszycie są zanotowane ich adresy zamieszkania na Podtatrzu. Warto byłoby odwiedzić krewnych, zarejestrować ich opowieści, obejrzeć rodzinne archiwa, przeprowadzić kwerendy w archiwum Wydziału Kul- 
tury Miasta Zakopanego, aby opisać działalność tego zespołu i jego oddźwięk $\mathrm{w}$ regionie.

$$
* * *
$$

Magdalena Kwiecińska - doktor, etnolog, absolwentka Instytutu Etnologii i Antropologii Kulturowej Uniwersytetu Jagiellońskiego. Jest członkiem Komisji Etnograficznej Polskiej Akademii Umiejętności, Polskiego Towarzystwa Ludoznawczego i Rady ds. Niematerialnego Dziedzictwa Kulturowego przy Ministrze Kultury i Dziedzictwa Narodowego. Pracuje w Dziale Etnograficznym Muzeum Tatrzańskiego im. Dra Tytusa Chałubińskiego w Zakopanem. Autorka publikacji, filmów dokumentalnych, scenariuszy i wystaw związanych z tematyką karpacką oraz kulturą Spisza i Podhala. Współautorka wystawy „Romscy kowale na Spiszu” (2018), książki Prosto z garnka. Tradycje kulinarne Romów (2017) i filmu dokumentalnego Romane Butia. Profesje romskie (2015). Laureatka Narody Województwa Małopolskiego im. Romana Reinfussa w 2019 roku.

mkwiecinska@muzeumtatrzanskie.pl 